\title{
Genotypic parameters for egg production in pure breed hens by using random regression model
}

\author{
Priscila Becker Ferreira ${ }^{1 *}$ Paulo Roberto Nogara Rorato ${ }^{1}$ Fernanda Cristina Breda ${ }^{1}$ \\ Vanessa Tomazetti Michelotti ${ }^{1}$ Alexandre Pires Rosa ${ }^{1}$ André Macedo ${ }^{1}$
}

'Departamento de Zootecnia, Centro de Ciências Rurais (CCR), Universidade Federal de Santa Maria (UFSM), Avenida Roraima, 1000, 97105-900, Santa Maria, RS, Brasil. E-mail: pri_zoot@hotmail.com. .Corresponding author.

\begin{abstract}
This study aimed to test different genotypic and residual covariance matrix structures in random regression models to model the egg production of Barred Plymouth Rock and White Plymouth Rock hens aged between 5 and 12 months. In addition, we estimated broad-sense heritability, and environmental and genotypic correlations. Six random regression models were evaluated, and for each model, 12 genotypic and residual matrix structures were tested. The random regression model with linear intercept and unstructured covariance (UN) for a matrix of random effects and unstructured correlation (UNR) for residual matrix adequately model the egg production curve of hens of the two study breeds. Genotypic correlations ranged from 0.15 (between age of 5 and 12 months) to 0.99 (between age of 10 and 11 months) and increased based on the time elapsed. Egg production heritability between 5- and 12-month-old hens increased with age, varying from 0.15 to 0.51 . From the age of 9 months onward, heritability was moderate with estimates of genotypic correlations higher than $90 \%$ at the age of 10, 11, and 12 months. Results suggested that selection of hens to improve egg production should commence at the ninth month of age. Key words: Barred Plymouth Rock, heritability, laying rate, White Plymouth Rock.
\end{abstract}

\section{Parâmetros genotípicos para produção de ovos em raças puras utilizando metodologia de modelos mistos}

RESUMO: Objetivou-se testar diferentes estruturas de matrizes de (co)variâncias genotípicas e residuais em modelos de regressão aleatória para modelar a produção de ovos do $5^{\circ}$ ao $12^{\circ}$ mês de idade de poedeiras das raças Plymouth Rock Barrada e Plymouth Rock Branca, bem como estimar a herdabilidade no sentido amplo e as correlações ambientais e genotípicas. Foram avaliados seis modelos de regressão aleatória e, para todos os modelos, foram testadas 12 estruturas das matrizes genotípicas e residuais. O modelo de regressão aleatória com intercepto linear com estrutura de (co)variância desestruturada (UN) para a matriz de efeitos aleatórios e correlação desestruturada (UNR) para a matriz de resíduos, modela adequadamente a curva de produção de ovos das aves das duas raças estudadas. As correlações genotípicas variaram de 0.15 (entre o $5^{\circ}$ e o $12^{\circ}$ mês) a 0.99 (entre o $10^{\circ}$ e o $11^{\circ}$ mês), aumentando conforme a proximidade entre os meses. As herdabilidades para a produção de ovos entre o $5^{\circ}$ e o $12^{\circ}$ mês de idade aumentam com o avanço da idade, variando de 0.15 a 0.51 . A partir do nono mês de idade a herdabilidade é moderada com estimativas de correlações genotípicas superiores a 90\% nos meses 10 , 11 e 12 . Sugere-se a seleção das poedeiras através de critérios fenotípicos a partir do $9^{\circ}$ mês de idade das aves.

Palavras-chave: Plymouth Rock Barrada, herdabilidade, taxa de postura, Plymouth Rock Branca.

\section{INTRODUCTION}

Search for new methodologies that may improve the selection of laying hens is important to achieve maximum egg production, since estimates of genetic and phenotypic parameters are the main tools to reach this maximum in the population, enabling better selection of laying strains.

The most significant economic traits are of a polygenic nature; and therefore, in breeding programs, animals are evaluated based on their performance. The phenotypic value of a given trait is the result of genetic heritage (genotype) of the animal in addition to environmental effects and the effects of the genotype/environment interaction. This suggested that the phenotypic value of the animal does not directly showed its genetic potential, as it is always influenced by the environment and the genotype/ environment interaction (FALCONER, 1981). Thus, egg production is a quantitative trait influenced by genetics and environment.

The mixed model methodology proposed by HENDERSON (1949) was used to evaluate the traits of economic importance that are expressed in individuals over time such as milk production (DORNELLES et al., 2015), growth in beef cattle 
(TINEO et al., 2016; LOPES et al., 2016), and egg production (CRUZ et al., 2016). These models allows to adjust the random production curve of each animal, expressed as deviation from the mean curve of the population or group of animals (BONAFÉ et al., 2011). The regressions are adjusted depending on the production period using ordinary polynomials, or other linear functions, and model trajectories for the population mean (fixed regressions) and for each animal (random regressions). Additionally, it provides estimates of genetic parameters at any point along the egg production curve in the interval in which the measurements have been obtained. The prediction of these values for egg production is of great economic importance, and should be considered when selecting laying hens (VENTURINI, 2012).

The aim of this study was (1) to define the random regression model that best fits the observed data of egg production of Barred Plymouth Rock and White Plymouth Rock hens between 5 and 12 months of age; (2) to test different structures of genotypic covariance matrices (random effect matrix G) and residuals (R); and (3) to estimate broad-sense heritability, and environmental and genotypic correlations.

\section{MATERIALS AND METHODS}

This study was conducted using egg production data from Barred Plymouth Rock (BPR) and White Plymouth Rock (WPR) hens raised during the year of 2010 in the Laboratory of Poultry of the Animal Science Department of Federal University of Santa Maria. Poultry were bred in a $210-\mathrm{m}^{2}$ experimental aviary, in laying cages $(\mathrm{L} 0.33 \times \mathrm{W}$ $0.45 \times \mathrm{H} 0.40 \mathrm{~m})$ housing two hens each, received water and food ad libitum, identical environmental management procedures, and an increasing lighting program of up to $17 \mathrm{~h}$ of light per day.

Percentage of eggs produced per cage was evaluated from 151 BPR $(\mathrm{n}=1.120)$ and 134 WPR hens $(\mathrm{n}=1.045)$, between age of 5 and 12 months. Estimate of egg production curve was obtained through a mixed model defined by the equation:

$$
Y_{i j}=\text { breed }+\sum_{m=0}^{k b-1} \beta_{m} \phi_{m}\left(t_{i}\right)+\sum_{m=0}^{k a-1} \alpha_{j m} \phi_{m}\left(t_{i j}\right)+E_{i j}
$$

where $Y_{i j}$ is the production of eggs in the $i$ th period, by the $j$ th hen; $\beta_{m}$ are the regression coefficients used to model the mean trajectory of the population; $\phi_{m}\left(t_{i}\right)$ is the regression function of order $k_{b}$ that describes the mean population curve according to the age at production $\left(t_{i}\right) ; \phi_{m}\left(t_{i j}\right)$ is the regression function that describes the trajectory of each hen $j$ according to its age in months $\left(t_{i}\right)$ for random genotypic effects; $\alpha_{i m}$ are the genotypic random regressors for each hen; $k_{b}$ and $k_{a}$ are the orders of the polynomials used for the purposes described above; and $E_{i j}$ is the random error associated with the age $(i)$ of a particular hen $(j)$.

Initially, the second and third order polynomial models were tested to estimate the mean trajectory of the population (fixed curve). Random effects were tested using the following polynomial regression models: (1) linear with intercept, (2) linear without intercept, (3) quadratic with intercept, (4) quadratic without intercept, (5) cubic with intercept, and (6) cubic without intercept.

For all random regression models described above, 12 genotypic variance and covariance (G) matrices were tested: variance component (VC), compound symmetry (CS), unstructured (UN), first - order autoregressive (AIR[1]), first - order heterogeneous autoregressive (ARH[1]), heterogeneous compound symmetry (CSH), toeplitz (TOEP), first - order auto regressive moving average (ARMA[1,1]), first - order and dependence (ANTE[1]), unstructured correlation (UNR), banded main diagonal (UN[1]), and Huynh-Feldt (H-F). To determine the optimal structure of the G matrix, the $\mathrm{VC}$ matrix was maintained as the covariance $(\mathrm{R})$ matrix, which assumes variance homogeneity, that is, the residual variances are the same throughout the egg-laying period. The mixed procedure of SAS ${ }^{\circledR}$ software (SAS Institute Inc., Cary, NC, USA 2010) was used for these analyses.

The best $\mathrm{G}$ matrix structure was selected based on the Akaike information criterion (AIC) (AKAIKE, 1974), the Bayesian information criterion (BIC) (SCHWARZ, 1978), the restricted log likelihood (-2LMR), the mean squared residue (MSR), and a graphical display. It is worth noting that lower -2LMR, AIC, BIC, and MSR values are preferred. After selection of the best $G$ matrix structure, the $G$ matrix was fixed and the 12 covariance matrices for residual effects ( $\mathrm{R}$ matrix) were tested.

The estimate of the broad-sense heritability $\left(h^{2}{ }_{a}\right)$ for each month $(t)$ of egg production was calculated as follows: $\quad h_{a\left(t_{i}\right)}^{2}=\frac{\hat{g}_{t_{i}}}{\hat{g}_{t_{i}}+\hat{\sigma}_{\dot{\theta}}^{2}}$, where $\hat{g}_{t_{i}}$

is the genotypic variance in the month $t_{i}$ and $\hat{\sigma}_{e}^{2}$ is the residual variance. The estimates of genotypic correlation between measurements in different months of laying $\left(t_{i}\right.$ and $\left.t_{j}\right)$ were defined by the equation $\hat{g} t_{i} t_{j}=\frac{\hat{g} t_{i} t_{j}}{\sqrt{\hat{g} t_{i} t_{j} \hat{x} t_{i} t_{j}}}$. The estimates of genotypic covariance for the month $t$ were described as $\hat{g} t_{i} t_{j}=Z_{t_{i}}^{\prime} K_{a} Z_{t_{j}}$, 
where $i=5,6, \ldots, 12$ and $j=5,6, \ldots, 12$ months of age; $K_{a}$ is the covariance matrix between the random genotypic regression coefficients; and $Z$ is the age matrix in months, in which each row represents an age and the number of columns is equal to the polynomial adjustment order used to calculate the variances $t_{i}=t_{j}$. Genotypic value of hens for egg production at different age were estimated as follows:

$\mathrm{VG}=\bar{X}_{p}+h_{a}^{2}\left(X_{i}-\bar{X}_{p}\right)$, where $\bar{X}_{p}$ is the phenotypic mean of all hens belonging to the same breed estimated by the fixed curve andis the phenotypic value of each hen. After that the ranking correlation (Spearman) of hens at different age were estimated.

\section{RESULTS AND DISCUSSION}

The fixed curve was modeled by second and third order polynomial regressions using 12 matrix structures of the random variance and covariance matrix $(G)$, maintaining the residual effects matrix
(R) always equal to the VC. For all 24 combinations $\mathrm{R}-\mathrm{G}$ that converged, the best values of $-2 \mathrm{LMR}$, AIC, BIC, and MSR were obtained when the third order polynomial regression was used to model the fixed curve. VENTURINI et al. (2012) used random regressions to assess the production of eggs in laying hens and defined the fixed trajectory of the curve by a cubic Legendre polynomial.

Regarding the best structure of the covariance matrix for random effects $(G)$, lower values of $-2 \mathrm{LMV}, \mathrm{AIC}, \mathrm{BIC}$, and residuals were observed for the UN matrix in random quadratic regression models with intercepts (model 3), followed by the cubic model without intercept (model 6) (Table 1). According to FLORIANO et al. (2006), several methods were developed to facilitate the choice of the covariance structure that best explains the variability behavior and correlation between repeated measures, with AIC and BIC being the main selection criteria, as they depend on

Table 1 - Restricted log likelihood (-2LMV), Akaike information criterion (AIC), Bayesian information criterion (BIC), residuals, and parameter numbers of the models (NP) for different structures of the random covariance $(\mathrm{G})$ matrix, with residual covariance (R) matrix equal to $\mathrm{VC}$ and the fixed curve modeled by third order (cubic) polynomial regression.

\begin{tabular}{|c|c|c|c|c|c|c|c|}
\hline \multicolumn{2}{|c|}{----------Structures--------- } & \multirow{2}{*}{ Models $^{1}$} & \multicolumn{5}{|c|}{-Statistical criteria------ } \\
\hline $\mathrm{R}$ & G & & NP & -2LMV & AIC & $\mathrm{BIC}$ & Residual \\
\hline $\mathrm{VC}$ & $\mathrm{UN}$ & 1 & 4 & 7854 & 7862 & 7877 & 160 \\
\hline $\mathrm{VC}$ & $\mathrm{UN}$ & 2 & 2 & 7996 & 8000 & 8007 & 201 \\
\hline $\mathrm{VC}$ & $\mathrm{UN}$ & 3 & 7 & 7765 & 7779 & 7805 & 137 \\
\hline $\mathrm{VC}$ & $\mathrm{UN}$ & 4 & 4 & 7917 & 7925 & 7939 & 172 \\
\hline $\mathrm{VC}$ & $\mathrm{UN}$ & 6 & 7 & 7788 & 7802 & 7827 & 142 \\
\hline $\mathrm{VC}$ & $\mathrm{VC}$ & 1 & 3 & 7980 & 7986 & 7997 & 196 \\
\hline $\mathrm{VC}$ & $\mathrm{VC}$ & 2 & 2 & 7996 & 8000 & 8007 & 201 \\
\hline $\mathrm{VC}$ & $\mathrm{VC}$ & 4 & 3 & 7994 & 8000 & 8011 & 199 \\
\hline $\mathrm{VC}$ & $\mathrm{CS}$ & 1 & 3 & 7995 & 8001 & 8012 & 200 \\
\hline $\mathrm{VC}$ & $\operatorname{AR}(1)$ & 1 & 3 & 7995 & 8001 & 8012 & 200 \\
\hline $\mathrm{VC}$ & ARH(1) & 1 & 4 & 7854 & 7862 & 7877 & 160 \\
\hline $\mathrm{VC}$ & $\mathrm{CSH}$ & 1 & 4 & 7854 & 7862 & 7877 & 160 \\
\hline $\mathrm{VC}$ & TOEP & 1 & 3 & 7995 & 8001 & 8012 & 200 \\
\hline $\mathrm{VC}$ & TOEP & 2 & 2 & 7996 & 8000 & 8007 & 201 \\
\hline $\mathrm{VC}$ & ANTE(1) & 1 & 4 & 7854 & 7862 & 7877 & 160 \\
\hline $\mathrm{VC}$ & ANTE(1) & 2 & 2 & 7996 & 8000 & 8007 & 201 \\
\hline $\mathrm{VC}$ & ANTE(1) & 4 & 4 & 7917 & 7925 & 7939 & 172 \\
\hline $\mathrm{VC}$ & UNR & 1 & 4 & 7854 & 7862 & 7877 & 160 \\
\hline $\mathrm{VC}$ & UNR & 2 & 2 & 7996 & 8000 & 8007 & 201 \\
\hline $\mathrm{VC}$ & $\mathrm{UN}(1)$ & 1 & 4 & 7980 & 7986 & 7997 & 196 \\
\hline $\mathrm{VC}$ & $\mathrm{UN}(1)$ & 2 & 2 & 7996 & 8000 & 8007 & 201 \\
\hline $\mathrm{VC}$ & $\mathrm{UN}(1)$ & 4 & 4 & 7994 & 8000 & 8011 & 199 \\
\hline $\mathrm{VC}$ & $\mathrm{H}-\mathrm{F}$ & 1 & 4 & 7854 & 7862 & 7877 & 160 \\
\hline $\mathrm{VC}$ & $\mathrm{H}-\mathrm{F}$ & 4 & 5 & 7917 & 7925 & 7939 & 172 \\
\hline
\end{tabular}

${ }^{1}$ Random regression models: $1=$ linear with intercept, $2=$ linear without intercept, $3=$ quadratic with intercept, $4=$ quadratic without intercept, $5=$ cubic with intercept, and $6=$ cubic without intercept. 
the likelihood ratio value of the model, the number of observations, and the parameters used.

In this study, the best covariance structure for residual effects (R) was assessed. For this assessment, the UN structure for the G matrix and the quadratic model with intercept, the cubic model without intercept, and the linear model with intercept were used (Table 2). In Table 2, the models that had the lowest -2LMV and AIC values were: linear with the intercept $\mathrm{G}=\mathrm{UN}$ and $\mathrm{R}=\mathrm{UNR}$; linear with intercept $\mathrm{G}=\mathrm{UN}$ and $\mathrm{R}=\mathrm{ANTE}$ (1). The BIC identified ANTE (1) as best structure of R matrix, followed by ARH (1).

The model that used the UNR structure for $\mathrm{R}$ matrix was not pointed as the best for BIC. To calculate the BIC, beyond LMV, the number of parameters of the model multiplied by the natural logarithm of total records, resulting in more rigorous penalty compared to AIC which considers only the number of parameters. This may be the explanation for the $\mathrm{R}=\mathrm{UNR}$ model have been the third in this criterion, since it has a higher number of parameters when compared to the other two models (38 vs 15 and 18 parameters).

In carrying out the graphic display of the observed and estimated production of eggs for each animal it was observed that the linear model with intercept $\mathrm{G}=\mathrm{UN}$ and $\mathrm{R}=\mathrm{UNR}$ was the best fit for the production curve of eggs per animal, with $83 \%$ and $87 \%$ efficiency for BPR and WPR hens, respectively, while the other models did not reach $76 \%$ efficiency, independent of breed (model with intercept $\mathrm{G}=\mathrm{UN}$ and $\mathrm{R}=\mathrm{ANTE}(1)$, and quadratic model with intercept $\mathrm{G}=\mathrm{UN}$ and $\mathrm{R}=\mathrm{ARH}(1))$.

In the figure 1 it can be observed the curve estimated by linear model with intercept $\mathrm{G}=\mathrm{UN}$ and $\mathrm{R}=\mathrm{UNR}$ for four different animals in each breed. With this information is possible to identify the animals that have curves over the average of the breed (fixed), such as the Plymouth Rock White animals 6119 and 6132 (Figure 1A) and the Barred Plymouth Rock animals 6030 and 6212 (Figure 1B).

Environmental correlation estimates between different months of egg production were low, ranging from 0.21 to 0.24 (Table 3). Genotypic correlation estimates ranged from 0.15 to 0.99 , with the largest estimates observed between proximal months (Table 3 ), that is, the best animals in month 5 may not be the best in months 10,11 , and 12 .

The broad sense heritability estimates for egg production in hens aged between 5 and 12 month ranged from 0.15 to 0.51 (Table 3 ). These values set a limit to the narrow-sense heritability

Table 2 - Restricted log likelihood (-2LMV), Akaike information criterion (AIC), Bayesian information criterion (BIC), residuals, and parameter numbers of the models (NP) for different structures of the residual covariance (R) matrix, with random covariance $(\mathrm{G})$ matrix equal to UN and the fixed curve modeled by third order (cubic) polynomial regression.

\begin{tabular}{|c|c|c|c|c|c|c|}
\hline \multicolumn{2}{|c|}{----------Structures----------- } & \multirow{2}{*}{ Models $^{1}$} & \multicolumn{4}{|c|}{ 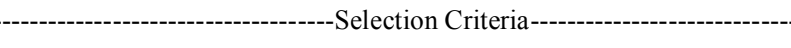 } \\
\hline $\mathrm{R}$ & G & & NP & $-2 \mathrm{LMV}$ & AIC & $\mathrm{BIC}$ \\
\hline $\mathrm{VC}$ & UN & 1 & 4 & 7854 & 7862 & 7877 \\
\hline $\mathrm{VC}$ & $\mathrm{UN}$ & 3 & 7 & 7765 & 7779 & 7805 \\
\hline $\mathrm{VC}$ & UN & 6 & 7 & 7788 & 7802 & 7827 \\
\hline $\operatorname{AR}(1)$ & UN & 1 & 5 & 7794 & 7804 & 7823 \\
\hline $\operatorname{AR}(1)$ & UN & 3 & 8 & 7740 & 7756 & 7785 \\
\hline $\operatorname{AR}(1)$ & UN & 6 & 8 & 7759 & 7775 & 7804 \\
\hline ARH(1) & UN & 1 & 12 & 7559 & 7583 & 7627 \\
\hline $\mathrm{ARH}(1)$ & UN & 3 & 15 & 7540 & 7570 & 7625 \\
\hline TOEP & UN & 6 & 7 & 7788 & 7802 & 7827 \\
\hline $\operatorname{ARMA}(1,1)$ & UN & 1 & 6 & 7774 & 7786 & 7808 \\
\hline $\operatorname{ARMA}(1,1)$ & UN & 3 & 9 & 7722 & 7740 & 7773 \\
\hline UNR & UN & 1 & 39 & 7415 & 7493 & 7635 \\
\hline $\mathrm{CSH}$ & UN & 1 & 12 & 7622 & 7646 & 7690 \\
\hline $\mathrm{CSH}$ & UN & 3 & 15 & 7563 & 7593 & 7648 \\
\hline $\operatorname{ANTE}(1)$ & $\mathrm{UN}$ & 1 & 18 & 7473 & 7509 & 7574 \\
\hline UN(1) & UN & 1 & 39 & 7622 & 7644 & 7685 \\
\hline UN(1) & UN & 3 & 42 & 7563 & 7591 & 7642 \\
\hline
\end{tabular}

${ }^{1}$ Random regression models: $1=$ linear with intercept, $2=$ linear without intercept, $3=$ quadratic with intercept, $4=$ quadratic without intercept, 5 = cubic with intercept, and $6=$ cubic without intercept. 


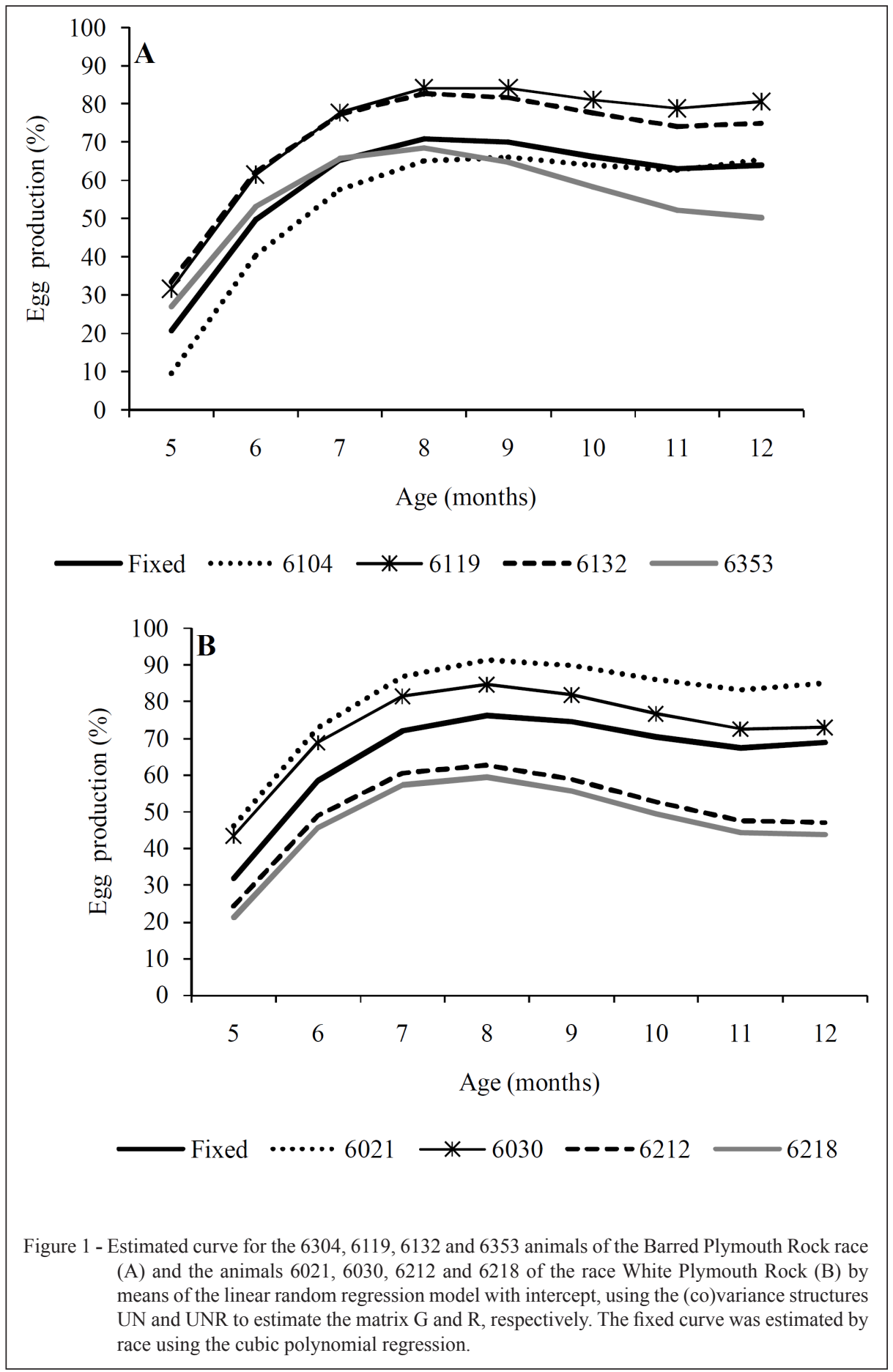

value, which considers only additive genetic variance. Heritability estimates were obtained in determined times; however, random regression models allowed to estimate the heritability at any point within the study period.
Results indicated that higher environmental influences were seen at the beginning of the laying period and decrease over time; therefore, phenotypic selection should not be made in the initial months. From the age of 9 months on ward, the heritability 
Table 3 - Broad-sense heritability (diagonal) of egg production, environmental (below the diagonal) and genotypic (above the diagonal) correlations between the eggs produced by hens obtained at different stages of the egg production curve.

\begin{tabular}{lccccccccc}
\hline Months & 5 & 6 & 7 & 8 & 9 & 10 & 11 & 0.12 \\
\hline 5 & 0.15 & 0.97 & 0.88 & 0.73 & 0.56 & 0.39 & 0.26 \\
6 & 0.24 & 0.24 & 0.97 & 0.87 & 0.73 & 0.59 & 0.47 \\
7 & -0.19 & -0.02 & 0.23 & 0.97 & 0.88 & 0.78 & 0.68 & 0.37 \\
8 & 0.07 & -0.07 & 0.18 & 0.35 & 0.97 & 0.91 & 0.85 & 0.78 \\
9 & -0.12 & -0.04 & -0.21 & -0.14 & 0.42 & 0.98 & 0.95 & 0.90 \\
10 & 0.01 & -0.04 & -0.06 & -0.15 & 0.70 & 0.49 & 0.99 \\
11 & 0.09 & -0.08 & 0.09 & 0.04 & 0.09 & 0.14 & 0.42 \\
12 & -0.21 & 0.13 & -0.08 & -0.30 & -0.08 & -0.05 & 0.07 & 0.85 \\
\hline
\end{tabular}

value was considered moderate $(0.42)$, with high correlation estimates with the age of $10(0.98), 11$ (0.95), and 12 (0.90) months. ANANG et al. (2000) reported high heritability for monthly egg production in Leghorn hens, which ranged from 0.18 to 0.47 , and suggested that egg production should be evaluated between the age of 5 and 10 months. SAVEGNAGO et al. (2011) analyzing the 17 to 30 week old laying rate of White Leghorn laying hens selected by seven generations for egg production observed a heritability of 0.15. TONGSIRI et al. (2014) working with birds of the 11th generation of hens selected from the Plymouth Rock White and Rod Island Red breeds observed a heritability of 0.30 and 0.33 respectively for the characteristic egg production at 17 weeks of age. SHADPARVAR \& ENAYATI (2012), analyzing data from six generations of Mazandaran native laying hens selected at the eighth week of age, reported a heritability of 0.156 for the number of eggs produced, and reported a negative correlation for egg numbers and the age of the first egg.
High heritability for egg number (from 0.25 to 0.34 ) was also reported by NIKNAFS et al. (2012), WOLC et al. (2012) and QADRI et al. (2013) who reported egg production estimates for up to the age of 40 weeks. LUO et al. (2007) estimated that egg production heritability varied from 0.16 (26 to 27 weeks of age) to 0.54 (62 weeks of age), which values are corroborated by the results reported in the present study.

The ranking correlation estimates of hens' classification at different ages revealed low correlation of hens genotypic values between the initial and final months. The highest heritability value (0.51) was observed at the age of 12 months; therefore, higher response to the phenotypic selection is expected at this age.

Correlations of genotypic values between the ages of 9 and 12 months were 0.94 for WPR and 0.96 for BPR hens (Table 4), that is, selecting $20 \%$ of the best egg production hens in the ninth and twelfth month, 78 and $81 \%$ of the selected hens for BPR and WPR breeds, respectively will be the same.

Table 4 - Correlations between the genotypic values of eggs produced by Barred Plymouth Rock (above the diagonal) and White Plymouth Rock (below the diagonal) hens of different ages.

\begin{tabular}{lcccccccc}
\hline Age (months) & 5 & 6 & 7 & 8 & 9 & 10 & 11 & 12 \\
\hline 5 & & 0.97 & 0.89 & 0.78 & 0.66 & 0.55 & 0.45 & 0.37 \\
6 & 0.97 & & 0.97 & 0.90 & 0.81 & 0.73 & 0.65 & 0.58 \\
7 & 0.89 & 0.97 & & 0.98 & 0.93 & 0.87 & 0.80 & 0.75 \\
8 & 0.79 & 0.92 & 0.98 & & 0.98 & 0.95 & 0.91 & 0.87 \\
9 & 0.69 & 0.85 & 0.94 & 0.98 & & 0.99 & 0.97 & 0.94 \\
10 & 0.61 & 0.78 & 0.89 & 0.96 & 0.99 & & 0.99 & 0.98 \\
11 & 0.53 & 0.72 & 0.85 & 0.94 & 0.98 & 0.99 & & 0.99 \\
12 & 0.47 & 0.67 & 0.82 & 0.91 & 0.96 & 0.99 & 0.99 & \\
\hline
\end{tabular}




\section{CONCLUSION}

The random regression linear intercept model with Unstructured (UN) covariance structure for the random effects matrix $(\mathrm{G})$ and Unstructured Correlations (UNR) for residuals matrix (R) adequately model the egg production curve of Barred Plymouth Rock and White Plymouth Rock hens.

Egg production heritability estimates from the age of 9 months onward are moderate and the estimates of genotypic correlations between 9 with the age of 10, 11, and 12 months are above $90 \%$. Therefore, the phenotypic selection of Barred Plymouth Rock and White Plymouth Rock hens beginning at the age of 9 months is suggested, with the aim to anticipate the selection of hens for egg production, to decrease the range of generations, increase annual gain, and reduced production costs.

\section{REFERENCES}

AKAIKE, H. A new look at the statistical model identification. IEEE Transactions on Automatic Control, v.19, n.6, p.716-723, 1974. Available from: <http:/ieeexplore.ieee.org/stamp/stamp.jsp?tp=\&arnumber=1100705>. Accessed: Nov. 23, 2012. doi: 10.1109/TAC.1974.1100705.

ANANG, A. et al. Genetic and phenotypic parameters for monthly egg production in White Leghorn hens. Journal Animal Breeding and Genetics, v.117, n.6, p.407-415, 2000. Available from: <http:// onlinelibrary.wiley.com/doi/10.1046/j.1439-0388.2000.00258.x/pdf $>$. Accessed: Oct. 14, 2012. doi: 10.1046/j.1439-0388.2000.00258.x.

BONAFÉ, C.M. et al. Random regression models for description of growth curve of meat quails. Revista Brasileira de Zootecnia, v.40, n.4, p.765-771, 2011. Available from: <http://www.scielo.br/pdf/rbz/ v40n4/09.pdf $>$. Accessed: July 14, 2016.

CRUZ, V.A.R. et al. Seleção para a produção de ovos em períodos parciais e acumulados em linhagem de frango de corte comercial. Arquivo Brasileiro de Medicina Veterinária e Zootecnia, v.68 n.2, p.489-496, 2016. Available from: <http://www.scielo.br/scielo. php?pid=S0102-09352016000200489\&script $=$ sci arttext\&tlng $=$ PT $>$. Accessed: Aug. 14, 2016. doi: 10.1590/1678-4162-7906.

DORNELLES, M.A. et al. Genetic parameters for test day milk production of Holstein cows using factors and principal components analysis. Ciência Rural, v.45, n.6, p.1087-1092, 2015. Available from: <http://www.scielo.br/pdf/cr/2015nahead/16784596-cr-0103 8478cr20141076.pdf >. Accessed: Aug. 14, 2016. doi: $10.1590 / 0103-8478 \mathrm{cr} 20141076$.

FALCONER, D.S. Introdução à Genética Quantitativa. Viçosa, MG: UFV, 1981, 279 p. (Tradução: Silva. M.A. \& Silva, J.C.)

FLORIANO, E.P. et al. Ajuste e seleção de modelos tradicionais para série temporal de dados de altura de árvores. Ciência Florestal, v.16, n.2 p.177-199, 2006. Available from: <http://coral.ufsm.br/cienciaflorestal/ artigos/v16n2/A6V16N2.pdf $>$. Accessed: Sept. 12, 2012.

HENDERSON, C.R. Estimation of changes in herd environment Journal of Dairy Science, v.32, p.706-711, 1949.
LOPES, F.B. et al. Efeito da endogamia sobre pesos pré-desmame em bovinos da raça Nelore mocho criados a pasto no bioma Cerrado. Archivos de Zootecnia, v.65, n.250, p.177-182, 2016. Available from: <http:/www.uco.es/organiza/servicios/publica/az/php/img/ web/13_12_54_103688Efeito_017.pdf >.Accessed:Aug. 02, 2016.

LUO, P.T. et al. Estimation of genetic parameters for cumulative egg numbers in a broiler dam line by using a random regression model. Poultry Science, v.86, n.1, p.30-36, 2007. Available from: $<$ http://ps.oxfordjournals.org/content/86/1/30.full.pdf $>$. Accessed: June 10, 2012. doi: 10.1093/ps/86.1.30.

NIKNAFS, S. et al. Estimation of genetic parameters for body weight and egg production traits in Mazandaran native chicken. Tropical Animal Health and Production, v.44, p.1437-1443, 2012. Available from: <http://link.springer.com/article/10.1007/s11250-012-0084-6>. Accessed: July 20, 2016. doi: 10.1007/S11250-012-0084-6.

QADRI, F.S. et al. Genetic study on important economic traits in two strains of White Leghorn chicken. Indian Journal of Poultry Science, v.48, p.149-153, 2013. Available from: <http://www. indianjournals.com/ijor.aspx ?target $=$ ijor:ijps \&volume $=48 \&$ iss ue $=2 \&$ article $=003>$. Accessed: Aug. 20, 2016.

SAVEGNAGO, R.P. et al. Estimates of genetic parameters, and cluster and principal components analyses of breeding values related to egg production traits in a White Leghorn population. Poultry Science, v.90, n.10, p.2174-2188, 2011. Available from: $<$ http://ps.oxfordjournals.org/content/90/10/2174.full.pdf + html $>$. Accessed: Nov. 29, 2016. doi: 10.3382/ps.2011-01474.

SHADPARVAR, A.A.; ENAYATI, B. Genetic parameters for body weight and laying traits in mazandaran native breeder hens. Iranian Journal of Applied Animal Science, v.2, n.3, p.251256, 2012. Available from: <http://www.sid.ir/en/VEWSSID/J pdf/1034220120314.pdf>. Accessed: Nov. 14, 2016. doi: 10.4238/2012.July.10.18.

SCHWARZ, G. Estimating the dimensional of a model. Annals of Statistics, v.6, n.2, p.461-464, 1978.

TINEO, J.S.A. et al. Influência da idade e do peso no início do teste na análise genética de características de crescimento, reprodução e escores visuais de tourinhos Nelore em provas de ganho em peso a pasto. Archivos de Zootecnia, v.65, n.249, p.29-34. 2016. Available from: $\quad<$ http://www.uco.es/organiza/servicios/publica/az/php/img/ web/18_13_49_05_3621_Idade_070.pdf $>$. Accessed: Aug. 10, 2016.

TONGSIRI, S. et al. Genetic parameters for production traits of Rhode Island Red and White Plymouth Rock Breeds selected under tropical condition in Thailand. In: WORLD CONGRESS OF GENETICS APPLIED TO LIVESTOCK PRODUCTION, 10., CGALP, 2014. Available from: $<$ https://asas.org/docs/defaultsource/wcgalp-posters/854_paper_9252_manuscript_516_0.pdf $>$. Accessed: Nov. 20, 2016.

VENTURINI, G.C. et al. Estimation of genetic parameters for partial egg production periods by means of random regression models. Genetics and Molecular Research, v.11 n.3, p.1819-1829, 2012. Available from: $<$ http://www.funpecrp.com.br/gmr/year2012/vol11-3/pdf/gmr1697. pdf $>$. Accessed: Mar. 14, 2013. doi: 10.4238/2012.July.10.18.

WOLC, A. et al. Genetic parameters of egg defects and egg quality in layer chickens. Poultry Science, v.91, n.6, p.1292-1298, 2012. Available from: <http://ps.oxfordjournals.org/content/91/6/1292.full. pdf+HTML > . Accessed: July 14, 2016. doi: 10.3382/ps.2011-02130. 